\title{
Reversing the Paradigm with Walter Gropius: Architecture Theory as a Social Solution
}

\author{
Susan Kelly Archer, Ph.D., Ed.D. \\ Mitchell College \\ 437 Pequot Avenue \\ New London, CT 06320, USA
}

(904)-655-1325

\begin{abstract}
The traditional paradigm for the study of architecture theory is through an historical lens, to develop an appreciation for the values and principles of a particular era through its artifacts. Shifting this paradigm, architecture theory can, and should, serve as a basis for analyzing contemporary social problems and seeking their solutions. Research repeatedly finds that economic inequality is a global problem, and in many cases, an underpinning of social unrest. Economic inequity is a significant world issue, that must be addressed by multiple disciplines working together to develop comprehensive solutions. One manifest variable for economic inequity is a lack of adequate, affordable housing. This paper investigated Modernist architect Walter Gropius' theories on standardization, design, and construction to address the housing variable. As part of a comprehensive solution, the architecture discipline to draw from its past, including the forward-thinking ideas of leaders like Walter Gropius, to contribute to this solution.
\end{abstract}

Keywords: Gropius, architecture history, architecture theory, affordable housing, prefabrication

\section{Introduction}

The traditional paradigm for the study of architecture and its related theory is through an historical lens, with the objective of developing an appreciation for the values and principles of a particular era through its artifacts. By shifting this paradigm, it is clear that architecture theory can, and should, serve as a basis for analyzing contemporary social problems and seeking their solutions. Research repeatedly finds that economic inequality is a global problem, and in many cases, an underpinning of social unrest. One manifest variable (part of a much larger whole) for economic inequity is a lack of adequate, affordable housing. Modernist architect and theorist, Walter Gropius, developed ideas about norms and standards, design and construction, and the architect's social obligation, that can be analyzed with respect to the problem of housing availability and affordability, as a representative of economic inequity. Although there is no panacea for the world's social problems, the universality of Gropius' ideas and the associated grounded theory would certainly allow a progressive approach to developing solutions for a persistent societal ill.

\subsection{Identification of the Problem}

Think tank organizations across the globe examine multiple trends to identify and then propose solutions for farreaching problems. One such organization, the World Economic Forum, recognized that current economic systems continue to contribute to worsening global inequalities (Hutt, 2016). "Extreme inequality may damage trust and social cohesion and thus is also associated with conflicts," according to a report prepared for the International Monetary Fund's Strategy, Policy, and Review Department (Dabla-Norris et al., 2015, p.9). While this report focused primarily on themes of financial markets, education, and technology, other authors have proposed a direct link between housing and economic inequities. Angélil and Siress (2012) discussed the banlieue, neighborhoods on the outskirts of Paris, as a model for examining global urban economic problems including poverty and marginalization. The banlieue included low-income housing projects, was populated primarily by immigrant families, and was branded as a haven for widespread poverty, unemployment, and violence. Social and spatial disproportions resulting from class and ethnic territorial segregation led to tensions that manifested in repeated riots, indicative of the lack of success engendered by France's post-World War II urban policies (Angélil \& Siress, 2012). However, low-income housing was not just an urban phenomenon. Ramirez and Villarejo (2012) focused their examination of low-income housing on the rural slums of post-World War II California, designed for temporary agricultural workers. From 1962 through 1964, the Braceroprogram allowed 4 million Mexican national men to enter the United States to fill agricultural labor needs. The program included relaxed housing and wage regulations that Ramirez and Villarejo (2012) argued exacerbated problems related to low-income housing availability. The resulting rural slums were very similar to urban slums of the post-World War II era, both consequences of labor demands. A variety of issues have been associated with housing design and construction in both rural and urban slums. 
Historically, the emphasis of housing design had been "for the more-wealthy population to satisfy each individual's tastes, disregarding durability, good workmanship and a need for less expensive housing for the poor" (Wingler, 1969, p. 20). Although low-income housing has been recognized as a significant global problem for decades, a number of architects and theorists have suggested multiple solutions or components for solutions that could have been used to address the problem. One of these architects was Walter Gropius.

\section{Gropius' Theoretical Foundation}

Gropius' lifelong concerns as an architect and a theorist included the design problem of developing affordable mass housing. One of his earliest projects, to provide housing for workers on his uncle's farm in 1906, may have served as a foundation for the formulation of Gropius' thoughts about the unrealistic nature of attempting to solve the financial problems associated with housing without a comprehensive plan (Gropius, 1972).The cost of a single-family dwelling increased by $93 \%$ between 1913 and 1937, making affordable housing a significant problem that many architects and other intellectuals believed must be addressed (Bureau of Labor Statistics, as quoted in Giedion, 1992). During this period, Germany (Gropius' home) and Eastern Europe saw overwhelming destabilization in economic, social, and political conditions (Vallye, 2011). Gropius (1965)later wrote that one of the underlying purposes of a national economy was finding methods by which the community's needs could be met at the lowest cost, which in turn required studied improvements to its manufacturing sector. This belief about a national responsibility may have derived from the cultural setting of his early work. From the turn of the $20^{\text {th }}$ century through the beginning of World War I, Germany grew in stature within the disciplines of economics, politics, and military strength. This growth led to development of vastly different cultures of leadership: one comprised of military and public officials attracted to the powerful possibilities associated with new concepts of industrialization; and the other that included intellectuals who believed that the industrialization required more meaning (Giedion, 1992). The efforts of the intellectual community could be summed in a statement from the 1908 constitution of the German Werkbund, "The aim of the League is to raise the standard of manufactured products by the joint efforts of art, industry and craftsmanship" (Giedion, 1992, p. 21). However, because German architecture of the time was focused primarily on accommodating the country's wealthy middle class, the Arts and Craft Movement prevailed until the war began. Prior to World War I, there was a distinct opposition to the Modernist embrace of industrialization and standardization of form.

Gropius recognized the resistance of the craft movement to mechanization and automation of manufacturing. He attempted to stave this opposition by extolling the potential of these advances as eliminating physical labor for subsistence and replacing it with an ability to achieve at a more advanced or intellectually sophisticated level. He believed it was the responsibility of the architect to coalesce the structural, mechanical, social and economic problems that were associated with buildings, in order to develop an understanding of how an individual dwelling or building was one cell of a larger organism (Fitch, 1960). As early as 1910, Gropius proposed solutions to the housing problem in Europe, as well as to the problem of the downfall of the city. His suggestions were for the industrialization of house building through a basic uniform style that would provide "low-cost, well-built and practical houses in good taste" (Wingler, 1969,p. 20). He also considered the necessity for individual variations, as long as they were in keeping with the general uniformity of design. Gropius grew to see the architect as a coordinator, responsible for the myriad activities related to a building, which led to a further expansion of his perception that the architect must understand the function of a street, and then the town, and beyond to regional and national planning. This comprehensive sphere of influence would have at its center the most basic, repeatable component that could become any type of construction through variation of combination.

\section{Norms and Standardization}

To realize Gropius' proposal for industrialized house building, both the design and construction communities would have to use standard-sized components and materials for all houses. He opined that the necessities of life were usually similar, so homes should "satisfy homogeneous needs, uniformly and consistently" (Wingler, 1969,p. 126). Gropius did not believe there was a practical justification in allowing each house to have a different floor plan, shape, style, and to be made from different building materials. The individuality of each unit would be in the choice of a variation of one basic house, furnishings, and size due to the number of inhabitants. He promoted the necessity of limiting mass production to standardized components to reduce production costs and extend those savings to tenant rents or buyer prices (Giedion, 1992).

Gropius led multiple projects that derived directly from his belief that an infinite number of combinations of standardized elements could uphold individual tastes in design while taking advantage of the cost efficiencies associated with mass production. In 1923, he directed a Bauhaus project to design a model for standardized houses (Gropius, 1972). 
The model was actually designed as combinations of basic house units that could be arranged in different groupings so that houses of different sizes and with different façades could be constructed. These multiple configurations were an early attempt to address the dialectic of standardization and variability (Gropius, 1972). Gropius believed the multiple use of a completed series of plans would save money and design time, and by using the same materials for all houses, these materials could be mass-produced, and construction would be much less expensive. However, he recognized the need for mass-market prefabrication to have an architecturally controlled basis, "It is well to remember that industry rarely distinguishes between what is simple and beautiful, and what is simple and ugly" (Heyer, 1966,p. 211). His theory was that the architect should work closely with the manufacturing industry for the benefit of the consumer, in order to optimize the combination of standardization and flexibility, increasing economic efficiency of design and construction while preventing mass-monotony. Gropius defined a standard as a basic realistic prototype of any item in general use which would represent the combination of the best of its precedent and component forms. He believed this combination should be a reduction from any original so that non-generic elements, non-essential features, and the designer's personal context were removed, allowing the development of a norm (Gropius, 1965). He sought to dispel what he termed a myth of standardization tyranny by referring to recognized historical periods in which type-forms had been adopted by civilizations as a criterion for facilitating order (Gropius, 1965).

\section{Design and Construction}

An early Gropius project that addressed how to develop mass housing was the design for workers' housing at Törten, Dessau in 1928. This design consisted of a series of individual living areas that were component parts of a single housing unit laid out in a straight line like a railroad. Each unit would be constructed from prefabricated materials that could be assembled in a linear process using a movable crane (Agren \& Wing, 2014). Gropius' supporters called the project an "ingenious and varied use of prefabricated parts" and said that he had reached the milestone of being the first to use concrete on a mass-production scale (Forsee, 1966, p. 74). His critics argued that "component units are all very well, but homes are a personal affair and must have an individual appearance" (Forsee, 1966,p. 74). The critics' comments reflected the more common public opinion at that time and Gropius' plan was rejected. In 1929, he developed a project for middle class apartments in Siemenstadt, considered high-density housing (Heyer, 1966). The planning for this project included calculations of sun and light angles in order to provide the most easily and naturally lit individual units, an economic efficiency construct that continued to be a theme in Gropius'work. Two years later Gropius explored prefabrication of materials for copper houses in Finow, Germany. This particular project was very significant to his work with mass-production because it employed dry-assembly. He identified advantages such as eradication of moisture from the building process, use of easily transported lightweight components, freedom from seasonal construction constraints, and realization of low maintenance costs due to the use of high-quality materials (Gropius, 1972). Further logistical benefits included developing economies of scale by using standardized production, specifying a fixed price without expectation of added costs during construction, and reducing delivery time. The failure of the German economy in the early 1930s led to the closing of this project after experimental units were built, but the initial construction was very successful in meeting the prescribed benefits.

Gropius eventually moved to the United States, where he continued to champion the ideas of standardization, massproduction, and use of prefabricated materials. He believed the assembly-line method of production so steadfastly embedded in American society could be used to develop a model for the rest of the world. However, Gropius cautioned that this mass-production method demanded a guide to standards of excellence so that the resulting goods would possess technical quality and represent cultural significance. In 1941, he collaborated with Breuer to develop the Aluminum City Terrace Housing for Pittsburgh, Pennsylvania. This project was sponsored to provide housing for industrial workers supporting World War II manufacturing, and the architects were urged to develop a low-cost solution that would be an improvement over earlier projects in the area. Floor plans for individual dwellings were combinations of standardized units, and although initial reactions to the buildings were critical of the aesthetic value, by the end of the first year $89 \%$ of the residents were pleased with their homes (Gropius, 1972). Gropius continued to experiment with prefabrication in the design of a packaged house system for the late 1940s. Using the design for the earlier copper houses, he collaborated with Wachsmann to develop a house component system. The parts were interchangeable, and the architects created a three-dimensional interlocking metal joint to facilitate multiple configurations from the standardized parts (Agren \& Wing, 2104). Even though mass production was successful, the project only lasted three years because of antiquated financing methods that were still following traditional construction schedules rather than the more efficient pace of assembling prefabricated parts (Gropius, 1972). 
The practical aspect of theories on housing had not kept pace with the conceptual aspect. Later projects included Gropiusstadt outside Berlin, a village of neighborhoods complete with housing, utilities, community buildings, and green spaces, as well as building codes that required variations to standardized housing units, maximization of access to sunlight, and attention to both daytime and nighttime circulation (Gropius, 1972). In 1967 and 1968, Gropius collaborated with Cvijanovic to formulate a comprehensive plan for the town of Selb, Germany. The plan addressed a number of issues typical of the era: traffic patterns that impeded pedestrian access to central buildings, the need for greenspaces and both orientation toward the greenspace for housing, as well as access to the greenspace from housing. The plan also provided a strategy for making adjustments when necessary due to population growth (Gropius, 1972). These ideas of comprehensive design continued to be integral to Gropius' theoretical framework.He referred to a 20acre group of houses in Lexington, Massachusetts when discussing the difference between individual homes and highdensity housing,

Individual houses offered more peace, privacy and ease in supervision of children, but they were expensive, time consuming and made commuting distances longer. In concentrated population centers, high-rise apartments would be the solution. They could offer a maximum of air, sun, community facilities, and open parkland (Forsee, 1966,p. 84).

\section{Expandability}

The development of standardized components for individual residences, or for high-density housing could be expanded to conceptualizing outside the resulting buildings to their communities. Gropius recognized the significance of a total architecture as opposed to what he saw as a confluence of "unrelated partial improvements which lack organic cohesion" (Gropius, 1968, p. 8). He believed that all buildings should be part of an organism: a city. Gropius explained the progression from building to city as the interrelationships that generated the organism. The house or building would be the basic cellular unit, that combined with more basic cells to form the larger unit: the street. If the cells were uniform in structure, then when reproduced by adding streets, the organism/city as rows of housing with green open spaces would be the generated result (Cormier, 1986). Even with uniformity of the cells, Gropius saw the possibility of variation through diversity in the relative sizes of the houses or buildings (Gropius, 1965). Reflecting on historical trends, he suggested that the most venerated cities relied on reiteration of an accepted standard that served as a "common denominator of a whole period" (Gropius, 1965, p. 37). Superior urban cultures were defined by architectural character that demanded unification of its component elements. Applying this theoretical base to community planning and design would suggest the judiciousness of limiting the variety of building type so that the focus could be on improving their quality while reducing their cost, which Gropius believed would improve the socioeconomic status of the whole population. "Greater communal utility" would generate "deeper architectural significance" (Gropius, 1965, p. 38).

This total architecture was to embrace the entire environment, from the most basic tool to the most modern city. Gropius suggested that there were individual works, constructed in isolation at sites around the world, but their participation in surrounding conglomerations of often conflicting ideas had created an ugly and chaotic mess. The city of the $20^{\text {th }}$ century should exemplify life as an organic whole. He stated that an architect "should first reexamine fundamental relationships between man and man, and between man and nature, and not yield to the pressure of special interests or shortsighted enthusiasts who see mechanization as an end in itself" (Gropius, 1968, p. 7). He was concerned that rapid development of the machine and scientific discovery led to development of tools of civilization that had outgrown society, suggesting that architecture should adapt to the developments rather than allowing the machine to be both a means and an end product of the discipline (Hoag, \& Hoag, 1977). The specialization engendered by the machine age had intensified division rather than stimulating a convergence to understand existence as part of a whole.

Gropius believed that the relationships tying existence together were critical to the architect in planning individual projects and, as a result, shaping the world. He developed what he believed was the best plan for using prefabrication and mass production to create cost-efficient, appropriate buildings, in the form of the proposal, Systematic Preparation for Rationalized Housing Construction, for the German Third Reich (Wingler, 1969). It began with extensive research and then the expedition of the best plan researched. There were twenty-one steps to the research, including designing a master plan for the Reich to facilitate economic growth to support plans in the future, instituting a national housing finance plan, and enacting a legal basis for the entire process in the form of a city-planning statute. In his comprehensive design, Gropius also conceived of planning transportation facilities and centralized utilities to support the resulting communities and suggested performing empirical research to determine the most socioeconomically appealing home template that could include gardens, plans and materials. The proposal included explanations of the cost-effectiveness of using prefabricated materials, standardizing building techniques, and planning work shift 
arrangements in order to take full advantage of daily sunlight. The leadership of the Reich did not find the proposal necessary, perhaps in part because Adolf Hitler was not an admirer of the Modernist movement and Gropius' plan followed the Modernist ideal of designing an inclusive, utopian society.

\section{Conclusion}

In repeated proposals, projects, and designs, Walter Gropius developed a substantive argument for using prefabricated, standardized components that could be mass-produced in order to create cost-efficient housing for large numbers of people. Founded in early consideration of relationships between aesthetics and engineering construction as well as aesthetics and product design, Gropius' ideas supported a Modernist belief that standardization was a virtue (Banham, 1960, p. 68).As early as 1909, he was writing about how to bridge the dichotomous nature of prefabrication: his belief that the process of mass production could not be designed around complete construction of a house because it would deny "the public desire for a home with an individual appearance" (Gropius quoted in Giedion, 1992, p. 13). Gropius' design ideas attempted to close the standardization-variability gap by offering solutions that could accommodate different sized families. He experimented with a variety of materials to optimize production and minimize construction and maintenance costs. He expanded ideas related to single-home design to multi-unit dwellings and beyond to the street, the town, the region, and the nation. Giedion (1992) wrote of Gropius' life that he was "governed by sternly disciplined rational thinking" typically associated with the Modernist movement, but also possessed "an instinct for the line of future development that far transcend[ed] the logic of the moment" (p.12). During the 1930s, Gropius wrote that architecture had been released from what he believed was a confusion of ornament, with structural function assuming a prominent role in design (Hoag \& Hoag, 1977). He believed the ability of architecture to retain relevance was grounded in its practical value and a focus on "concise and economical solutions represent[ing] the purely material side of the formulizing process" (Hoag \& Hoag, 1977,p. 181). However, he noted that the aesthetic side of architecture, with its goal of satisfying the human soul, was equally essential in the unity that defined life.

In today's world, where economic disparities between wealthy and poor subgroups of the population, and the resulting despair have driven those living in poverty to sometimes take desperate action, it is imperative to revisit Gropius' life work as part of a comprehensive solution. By providing affordable housing that considers the individual needs of those who live in it, community leaders can begin to rebuild the self-respect of people who have traditionally felt disenfranchised, marginalized, and forgotten. It is equally important to re-examine Gropius' philosophical belief about the architect, most eloquently elaborated by a former student:

Gropius was the first man who interpreted the industrial revolution to us in terms of architecture, in terms of design, in terms of community planning. He constantly investigated the great potentialities of industrial society and showed us how to assimilate them to our ever-changing needs...he has shown us a place in society; ... he has taught that mechanization and individual freedom are not incompatible; ... he has explained to us the possibilities and values of communal action (Hoag \& Hoag, 1977,p. 183).

When reviewing Gropius' body of work, one must do so through an historical lens that places this work in its Modernist context. The Modernist movement was defined by a social agenda in which architecture would play an influential role in generating the ideal or utopian society. Modernity was a project to improve the world by improving life conditions from the multiple perspectives of economics, sociology, politics, and culture, with an ultimate goal of engendering equal opportunities for all (Heynen, 2014). Given the assumption that the Modernist movement closed in the late $20^{\text {th }}$ century, one would have to assess its success in achieving its utopian goal, based on the current state of those whose state Modernists sought to improve. Since the problem of economic inequity continues, and some might say the economic divide has widened, the ideas of Modern theorists might be easy to dismiss as unsuccessful. Another view of modernity should be incorporated in one's analysis: a more transitory effect based on the ever-changing nature of the individual, society, and the objects with which both interact (Heynen, 2014). Campkin's (2014) ideas on regeneration of low-income neighborhoods to integrate the input of affected communities, in an effort to "articulate positive reconfigurations of urban nature," could be the contemporary extension of Gropius' philosophy on improving the lives of marginalized groups by designing affordable, standardized building components for multiple constructions (p. 58). However, one must be careful not to confuse regeneration with gentrification. The housing must be designed for the individuals living in the affected communities, not designed to oust them.

The problem of affordable housing, and by extension economic equity, is not one that can be solved by a single set of ideas. To paraphrase Santayana, if today's thinkers choose to ignore the ideas of their predecessors, they are most likely condemned to repeat the same less-than successful results. Based on this statement, there is a certain degree of irony in looking to Walter Gropius for solutions to today's problems. 
When Gropius assumed control of the Bauhaus in the early 1900s, he revised the curriculum to focus students' efforts on learning the components of design, and the crafts related to architecture. However, he removed the study of architecture history from the curriculum.

Gropius believed that a school of architecture should be the "building of the future ... combin[ing] architecture, sculpture, and painting in a single form, and ... one day rise towards the heavens from the hands of a million workers as the crystalline symbol of a new and coming faith" (Gropius, 1919, para. 4). However, today's problem solvers can rectify this missing piece. Solutions should be viewed via a temporal lens: recall the best or most effective designs of the past and acknowledge future needs and potentials by looking forward, to develop the innovation in thought that should then lead to innovation in design (Carroll, 2013). Economic inequity is a significant world issue, that must be addressed by multiple disciplines working together to develop comprehensive solutions. It is the responsibility of the architecture discipline to draw from its past, including the forward-thinking ideas of leaders like Walter Gropius, in order to contribute to this conversation.

\section{References}

Agren, R., \&Wing, R.D. (2014). Five moments in the history of industrialized building.Construction Management and Economics,32(1-2, 7-15)https://doi.org/10.1080/01446193.2013.825374

Angélil, M., \&Siress, C. (2012 Mar). The Paris Banlieue: Peripheries of inequity.Journal of International Affairs, 65(2), 57-67.

Banham, R. (1960).Theory and design in the first machine age. MIT Press.

Campkin, B. (2014). On regeneration.In Borden, I., Fraser, M., \&Penner, B. (Eds). Forty waysto think about architecture: architectural history and theory today. Wiley, pp. 54-59.

Caroll, M. P. (2013).A critical analysis of Nikolaus Pevsner's theory of the origin of the modern movement. Thesis submitted to The University of Texas at San Antonio.

Cormier, L.H. (1986).Walter Gropius: Émigré Architect. Works and Refuge-England and America in the 30s. Dissertation submitted to Brown University.

Dabla-Norris, E., Kochhar, K., Suphaphiphat, N., Ricka, F., and Tsounta, E. (June 2015). Causes and Consequences of Income Inequality: A Global Perspective. International Monetary Fund Strategy, Policy, and Review Department.

Fitch, J.M. (1960). Walter Gropius. George Braziller, Inc.

Forsee, A. (1966).Men of modern architecture.Macrae Smith Co.

Giedion, S. (1992).Walter Gropius. Dover Publications, Inc.

Gropius, I. (1972).Walter Gropius: Buildings, plans, projects 1906-1969.MIT Press.

Gropius, W. (1919). Bauhaus manifesto, Bauhaus Archive.http://gropius.house/location/bauhaus-manifesto/

Gropius, W. (1965).The new architecture and the Bauhaus, translated by P. M. Shand, MIT Press.

Gropius, W. (1968).Apollo in the democracy, McGraw-Hill Book Co.

Heyer, P. (1966).Architects on architecture. Walker and Co.

Heynen, H. (2014). The Most Modern Material of Them All... In Borden, I.,Fraser, M., and Penner, B. (Eds). Forty ways to think about architecture: Architectural history and theory today. Wiley,pp. 95-99.

Hoag, E. and Hoag, J. (1977).Masters of modern architecture: Frank Lloyd Wright, Le Corbusier, Mies van der Rohe and Walter Gropius. Bobbs-Merrill Company, Inc.

Hutt. (2016). What are the ten biggest global challenges? Global Agenda, World Economic Forum, www.weforum.org/agenda/2016/01/waht-are-the-10-biggest-global-challenges

Ramirez, S. M., and Villarejo, D. (September 2012). Poverty, housing, and the rural slum: Policies and the production of inequalities, past and present. American Journal of Public Health, 102(9), 1664-1675.

Santayana, G. (1905). The Life of Reason.

Vallye, A. (2011).Design and the Politics of Knowledge in America, 1937-1967: Walter Gropius, Gyorgy Kepes. Dissertation submitted to Columbia University.

Wingler, H. (1969).Bauhaus.MIT Press. 